\title{
PENGARUH KREATIVITAS BELAJAR DAN SOFT SKILL MAHASISWA TERHADAP KESIAPAN KERJA MAHASISWA PENDIDIKAN BISNIS 2016
}

\author{
Fikranlim Hulu' ${ }^{1}$, Noni Rozaini ${ }^{2}$ \\ Jurusan Ekonomi \\ Fakultas Ekonomi, Prodi Pendidikan Bisnis Universitas Negeri Medan, \\ Jln. Williem Iskandar Pasar V Medan Estate. \\ fikranlim11@gmail.com, nonirozaini@gmail.com
}

\begin{abstract}
ABSTRAK
Penelitian ini bertujuan untuk mengetahui seberapa besar pengaruh kreativitas belajar dan soft skill mahasiswa terhadap kesiapan kerja. Penelitian ini dilakukan di Fakultas Ekonomi Universitas Negeri Medan dengan populasi seluruh mahasiswa Pendidikan Bisnis 2016 dan sampel berjumlah 96 orang. Dengan hasil analisis regresi linier berganda diperoleh persamaan garis linear $\mathrm{Y}=26,578+0,310 \mathrm{X}_{1}+0,422 \mathrm{X}_{2}$. Hasil uji $\mathrm{t}_{\text {hitung }}>\mathrm{t}_{\text {tabel }}$ untuk variabel kreativitas belajar dan $\mathrm{t}_{\text {hitung }}>\mathrm{t}_{\text {tabel }}$ untuk variabel soft skill dan uji f simultan $\mathrm{f}_{\text {hitung }}>\mathrm{f}_{\text {tabel. }}$. Hasil penelitian menunjukkan bahwa terdapat pengaruh positif dan signifikan antara pengaruh kreativitas belajar dan soft skill mahsiswa terhadap kesiapan kerja mahasiswa Pendidikan Bisnis 2016 Fakultas Ekonomi Universitas Negeri Medan
\end{abstract}

Kata kunci : Kreativitas Belajar, Soft Skill, Kesiapan Kerja 


\section{PENDAHULUAN}

Pertumbuhan dan yang saat ini semakin pesat pada era globalisasi diiringi pula dengan peningkatan persaingan pada berbagai bidang termasuk dalam hal pencarian kerja dan pasar dunia yang menghadapkan Indonesia pada persaingan ekonomi yang sangat luas. Di era globalisasi saat ini sangat menuntut tenaga kerja sebagai sumber daya yang berkualitas yang mampu berkompetisi dalam semua bidang dengan berbekalkan keahlihan yang profesional di bidangnya supaya dapat mengadapi dunia kerja yang terus berkembang

dan memenuhi tuntutan dunia kerja yang semakin kompleks.

Dewasa ini, salah satu masalah yang menarik untuk dikaji berkaitan dengan penyelenggaraan pendidikan mengenai kesiapan kerja mahasiswa. Saat ini banyak perusahaan atau usaha industri yang menolak pelamar kerja karena keahlian/kompentensinya tidak sesuai dengan dibutuhkan di dunia kerja. Hal ini mengakibatkan masalah pengangguran di Indonesia yang cukup mengkhawatirkan seiring dengan bertambahnya penduduk dari tahun ke tahun serta pengangguran yang semakin meningkat.

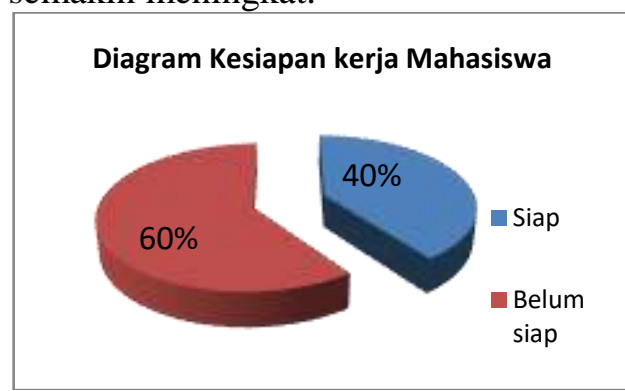

\section{Gambar 1. Diagram Kesiapan Kerja Mahasiswa Program Studi Pendidikan Bisnis 2016 Fakultas Ekonomi Univeritas Negeri Medan}

Berdasarkan observasi yang dilakukan menunjukkan bahwa kondisi kesiapan kerja mahasiwa Program Studi Pendidikan Bisnis 2016 juga ternyata masih rendah yang dimana dapat dilihat dari angket yang disebar kepada 40 responden mahasiswa dengan pernyataan saya sudah siap memikirkan dan merencanakan pekerjaan apapun mulai dari sekarang sesuai dengan keahlian, didapatkan sebesar $60 \%$ responden mahasiswa menjawab belum siap untuk bekerja. Sebesar $40 \%$ mahasiswa menjawab sudah siap untuk bekerja. Mahasiswa yang telah mendapatkan kelulusan seharusnya harus mampu untuk langsung bekerja.

Salah satu faktor kesiapan kerja adalah dari segi kreativitas belajar mahasiswa. Mahasiswa diharapkan mampu berpikir secara kreatif serta bertindak kritis dan memiliki daya inisiatif yang tinggi dalam belajar. Kreativitas belajar merupakan kemampuan seseorang untuk melahirkan sesuatu yang baru saat belajar, dapat berupa ide atau gagasan, baik dalam karya baru maupun kombinasi dengan hal-hal yang sudah ada. Kreativitas sangat diperlukan dalam bekerja karena pengembangan teknologi saat ini begitu pesat, sehingga memerlukan masalah yang dihadpinya. Oleh karena itu perlu dibina keterampilan berpikir kreatif pada diri mahasiswa agar dapat mengembangkan ide-ide kreatifnya selama menjalani proses belajarnya.

Observasi yang dilakukan diperoleh sebanyak 25 mahasiswa atau sebesar 62,5\% mahasiswa yang kemampuannya menghadapi masalah belajar rendah yang dimana dapat dilihat dari mereka rentan tidak mengerjakan soal atau tugas yang sulit. Hanya sebesar $40 \%$ kemampuan untuk berkembang dalam belajar, yang dimana mahasiswa membaca banyak buku atau referensi sebagai sumber dalam belajar, berbanding sangat kecil jika dibandingkan sebesar $60 \%$ tidak sama sekali membaca buku lain sebagai sumber referensi. Sebesar $57,5 \%$ terlihat minat berkreasi dalam belajar rendah yang dimana jika dalam mengerjakan soal atau tugas rentan tidak dari hasil pemikiran sendiri.

Selain dari kreativitas belajar mahasiswa faktor lain yang dapat menentukan kesiapan kerja mahasiswa. Mahasiswa diharapkan mempunyai soft skill dalam dirinya, soft skill yang dimaksud adalah sikap dan keperibadian yang dimiliki. Karena mahasiswa sebagai calon tenaga kerja harus memiliki keterampilan sikap sesuai dengan keahlian yang dimilikinya. Keahlian tersebut dipengaruhi oleh aspek soft skill yang dimiliki mahasiswa.

Dari observasi yang dilakukan diperoleh sebesar $50 \%$ manajemen waktu/kedisplinan tinggi dan rendah, hal ini dapat dilihat dari kedisplinan sehari-hari ketika jadwal berangkat kuliah terkadang masih ada yang sering terlambat dan merupakan masalah utama pada diri mahasiswa. 57,5\% soft skill nya rendah dilihat dari kejujuran mahasiswa 
pada saat mengerjakan atau pada saat ujian rentan tidak jujur arti kata berlaku curang atau mencontek.

terdapat beberapa masalah antara lain berkaitan dengan kreativitas belajar, soft skill dan kesiapan kerja mahasiwa. Kreativitas belajar mahasiswa dalam belajar masih rendah atau masih belum terlihat menyeluruh. Selain itu soft skill mahasiswa masih kurang terutama dalam beraptasi dengan lingkungan dan pengendalian emosi. Faktor utama yang mempengaruh kesiapan kerja adalah faktor pribadi mahasiswa. Kreativitas dan soft skill merupakan faktor dari dalam pribadi mahasiswa.

Bertolak dari uraian dan fenomena yang terjadi, perlu kiranya dilakukan penelitian untuk mengetahui kreativitas belajar dan soft skill mahasiswa terhadap kesiapan kerja mahasiswa program studi Pendidikan Bisnis 2016 Fakultas Ekonomi Universitas Negeri Medan, sehingga lulusan bisa menjadi faktor keunggulan dalam menghadapi persaingan pada era global sekarang dan masa yang akan datang

\section{KERANGKA TEORITIS Kesiapan Kerja}

Tuntutan persaingan dunia kerja mengharuskan sumber daya manusia memiliki kompetensi atau keahlian sehingga memiliki kesiapan-kesiapan kerja yang optimal. Kesiapan (readiness) dalam Kamus Lengkap Psikologi menurut Chaplin (2011:292) terdapat dua arti, pertama keadaan siap-siaga untuk mereaksi atau menanggapi dan kedua tingkat perkembangan dari kematangan atau kedewasaan yang menguntungkan bagi mempraktikkan sesuatu. Menurut Robert (2007: 292) menjelaskan kesiapan adalah kemampuan untuk menyiapkan diri secara spontan bagi peluang-peluang tidak terencana untuk tidak menjadi terlalu sibuk, berjalan tanpa sadar atau penuh dengan pikiran. Lebih lanjut menurut Slameto (2010:113) menyatakan bahwa "kesiapan adalah keseluruhan kondisi seseorang yang membuatnya siap untuk memberi respon atau jawaban dengan cara tertentu terhadap situasi".

Kerja (work) dalam Kamus Psikologi Lengkap berarti secara fisik merupakan kegiatan satu kekuatan yang bertindak melawan satu perlawanan, secara fisiologis merupakan pengeluaran energi selama kegiatan jasmani dan secara psikologi berarti penyelesaian suatu tugas (Chaplin, 2011: 540). Menurut Kartini (2009: 17) bekerja adalah aktivitas sosial bagi manusia dan memiliki dua fungsi pokok, yaitu memproduksi barang atau benda-benda dan jasa-jasa bagi diri sendiri dan orang lain dan mengikat individu pada pola interaksi manusiawi dengan individu lain, karena orang harus selalu bekerja sama dan berkomunikasi dengan orang lain untuk mempertahankan keberadaannya.

Menurut Abdul Hamid (1997: 22) berpendapat bahwa kerja terkadang disebabkan oleh dinamika berbagai persiapan. Kesiapan akan memuaskan individu dalam bekerja. Kesiapan kerja ini sesuai dengan minat dan kemampuan individu. Menurut Herminarto Sofyan dalam Marwanti dan Yuriani (2006: 13) kesiapan kerja adalah suatu kemampuan seseorang untuk menyelesaikan suatu pekerjaan sesuai

\section{Kreativitas Belajar}

Kreativitas belajar terjemahan dari kata "crativity" yang dalam bahasa inggris mempunyai akar kata "to create" yang artinya menciptakan. Kreativitas dibentuk dari dari kata kreatif sebagai kata sifat, sifat seseorang yang memiliki daya cipta. Pengertian tentang kreativitas ini sangat luas. Ada orang yang meninjau dari segi kreasi, sehingga dikatakan bahwa kreativitas itu hanya berhubungan dengan seni namun ada juga yag mengartikan kreativitas itu bukan saja yang berhubungan dengan seni. Kreativitas dapat didefinisikan secara berbeda-beda oleh pakar berdasarkan sudut pandang masing-masing. Perbedaan sudut pandang ini menghasilkan berbagai defenisi dengan pendekatan yang berbeda pula.

Menurut Utami Munandar (2009:12), mengatakan bahwa : Kreativitas adalah hasil interaksi antara individu dan lingkungannya. Seseorang mempengaruhi dan dipengaruhi oleh lingkungan dimana dia berada, dengan demikian baik perubah di dalam indvidu maupun didalam lingkungan dapat menunjang atau dapat menghambat upaya kreatif. Implikasinnya ialah bahwa kemampuan kreatif dapat ditingkatkan melalui pendidikan.

Sedangkan menurut Clark Moustakis (chietra 2008 diakses 19 Oktober 2019) menyatakan bahwa "kreativitas adala pengalaman mengekspresikan dan mengaktualisasikan identitas individu dalam 
bentuk terpadu dalam hubungannya dengan diri sendiri, dengan alam, dan dengan orang lain".

Tidak hanya kreativitas saja, belajar juga memiliki beberapa defenisi menurut para ahli. Menurut Sudarwan Danim (2014:93) "Belajar merupakan proses menciptakan nilai tambah kognitif, afektif, dan psikomotorik". Sedangkan menurut Oemar Hamalik (2013:27) "Belajar merupakan suatu proses, suatu kegiatan dan bukan suatu hasil atau tujuan".

\section{Soft Skill}

Konsep tentang soft skills sebenarnya merupakan pengembangan dari konsep yang selama ini dikenal dengan istilah kecerdasan emosional (emotional intelligence). Menurut Ary Ginanjar (2009: 285) tingkat IQ atau kecerdasan intelektual seseorang umumnya tetap, sedangkan EQ (kecerdasan emosional) dapat terus ditingkatkan.Sebagaimana dinyatakan Goleman dalam mengenal SQ (2000: 3) bahwa EQ merupakan persyaratan dasar untuk menggunakan IQ secara efektif. "Soft skills sendiri diartikan sebagai kemampuan diluar kemampuan teknis dan akademis (hard skills), yang lebih mengutamakan kemampuan pribadi seseorang bersosialisasi, berkomunikasi, kemampuan beradaptasi, mengelola diri sendiri dan orang lain serta bersikap optimis dalam semua bidang" (IEU Surabaya, 2010).

Soft skills merupakan keterampilan dan kecakapan hidup, baik untuk diri sendiri, hubungan dengan orang lain baik secara kelompok ataupun bermasyarakat, serta dengan Tuhan Yang Maha Esa. Seseorang yang memiliki soft skills yang baik akan semakin terasa keberadaannya di masyarakat. Menurut Elfindri (2010: 67) Soft skills meliputi beberapa hal yang berkaitan dengan: keterampilan akan berkomunikasi, keterampilan emosional, keterampilan berbahasa, memiliki etika dan moral, santun. Widhiarso (2009:1) mengatakan bahwa, Soft skills adalah seperangkat kemampuan yang mempengaruhi bagaimana kita berinteraksi dengan orang lain. Soft skills memuat komunikasi efektif, berpikir kreatif dan kritis, membangun tim, serta kemampuan lainnya yang terkait kapasitas kepribadian indivdu. Tujuan dari pelatihan soft skills adalah memberikan kesempatan individu untuk mempelajari perilaku baru dan meningkatkan hubungan antara pribadi dengan orang lain.

Dari kedua pendapat yang dijelaskan mengenai soft skills diatas disebut atribut soft skills. Lebih singkatnya lagi bahwa atribut soft skills adalah meliputi nilai yang dianut, motivasi, perilaku, kebiasaan, karakter dan sikap.

Soft skills dikatakan sebagai keterampilan yang paling penting dalam era globalisasi sekarang ini. Dalam dunia pendidikan terutama didalam pendidikan kejuruan, soft skills termasuk hal yang sangat penting peranannya. Dalam peningkatan atau perkembangan soft skills tidak harus dengan suatu pelatihan khusus dan terpisah dari kurikulum, tetapi merupakan satu kesatuan dari segala kegiatan pendidikan dalam lembaga pendidikan.

Soft skills dalam penelitian ini adalah kemampuan yang dimiliki seseorang yang lebih bersifat afektif yang memudahkan seseorang untuk memahami karakteristik diri sendiri, mengatur kepribadian dalam berkomunikasi, berpikir dan bersikap yang sesuai dengan norma masyarakat serta berinteraksi dengan lingkungannya sehingga mengantarkan dirinya pada kesuksesan.

\section{METODOLOGI PENELITIAN}

Penelitian ini dilaksanakan di Fakultas Ekonomi Universitas Negeri Medan yang berlokasi di jalan Willem Iskandar Pasar V Medan Estate. Populasi dalam Penelitian ini adalah seluruh mahasiswa pendidikan bisnis 2016 fakultas ekonomi universitas negeri medan yang berjumlah 96 mahasiswa. Berdasarkan ketentuan tersebut, maka sampel dalam penelitian ini ditetapkan sebanyak 96 orang. Uji instrument menggunakan uji validitas dan reliabilitas angket. Teknik analisa data dalam penelitian ini menggunakan analisis regresi berganda, uji hipotesis parsial (uji t), uji hipotesis simultan (uji f) dan koefisien determinasi (R2).

\section{HASIL DAN PEMBAHASAN}

Berdasarkan hasil perhitungan hipotesis secara parsial menunjukkan bahwa untuk variabel kreativitas belajar diperoleh $\mathrm{t}_{\text {hitung }}=2,359$ dengan taraf signifikan 0,020 Maka dari hasil tersebut nilai $t_{\text {hitung }}>t_{\text {tabel }}$ 
$(2,359>1,665)$ dan nilai signifikan $0.020<$ 0,05 . Dengan demikian hipotesis yang berbunyi terdapat pengaruh yang positif dan signifikan antara Kreativitas Belajar terhadap Kesiapan Kerja Mahasiswa Pendidikan Bisnis 2016 Fakultas Ekonomi Universitas Negeri Medan diterima.

Sementara dari variabel Soft Skill $t_{\text {hitung }}$ $=3,199$ dengan taraf signifikan 0,002 Maka dari nilai $t_{\text {hitung }}>t_{\text {tabel }}(3,199>1,665)$ dan nilai signifikan $0,002<0,05$. Dengan demikian hipotesis yang berbunyi terdapat pengaruh positif dan dan sigifikan antara Soft Skill terhadap Kesiapan Kerja mahasiswa Pendidikan Bisnis 2016 Fakultas Ekonomi Universitas Negeri Medan diterima. bawah ini:

Dapat dilihat dalam bentuk tabel di

Sumber: Pengolahan data dengan SPSS Versi 21

Dari pengujian hipotesis secara simultan antara kreativita sbelajar dan soft skill terhadap kesiapan kerja diketahui bahwa nilai $\mathrm{F}_{\text {hitung }}=$ 20,773, sedangka $F_{\text {tabel }} 3,10$ dengan taraf signifikan $0,000<0,05$ maka dapat disimpulkan bahwa $F_{\text {hitung }}>F_{\text {tabel }}(20,773>$ 3,10 ). Dengan demikian hipotesis diterima bahwa variabel indenpenden berpenngaruh simultan dan signifikan terhadap variabel dependen.

Tabel 2

Hipotesis Secara Simultan

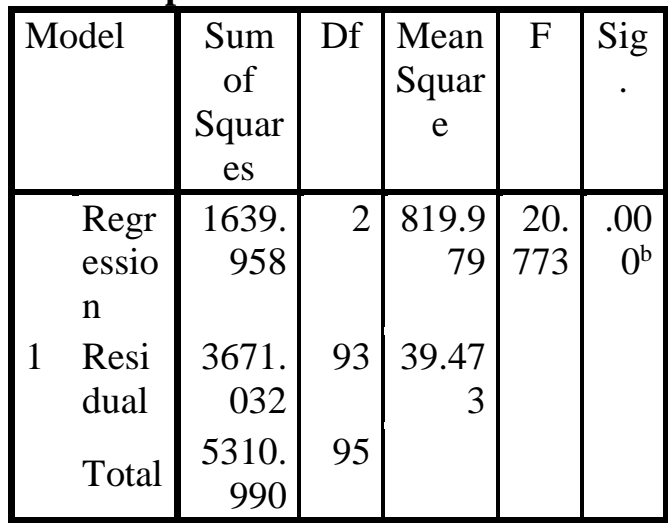

a. Dependent Variable: Kesiapan Kerja

b. Predictors: (Constant), Soft Skill,

Kreativitas Belajar

Sumber: Pengolahan data dengan SPSS Versi 21

Masing - masing variabel bebas juga memberikan pengaruh/sumbangan terhadap variabel terikat dengan uji R2 (Uji Determinasi) sebesar 0,309 atau sebesar $30,9 \%$. Dari data tersebut maka dapat disimpulkan bahwa dalam eeltian ini variabel Kreativitas Belajar (X1) dan Soft Skill (X2) memberikan sumbangan pengaruh sebesar 30,9\% terhadap Kesiapan Kerja (Y) dan sisanya 62,9\% disu

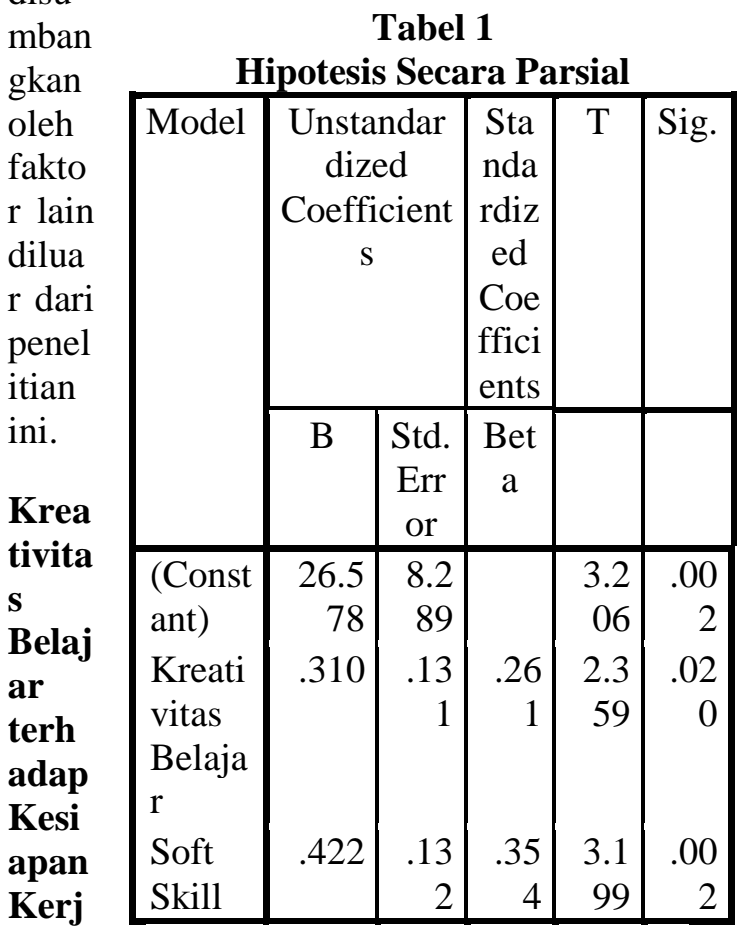

a

a. Dependent Variable: Kesiapan

Kerja

engaruh kreativitas belajar mahasiswa yang hanya sebesar 0,310 dilihat dari uji analisis regresi linear berganda ini bisa disebabkan karena mahasiswa kurang mampu menghadapi masalah dalam belajar dimana dapat dilihat kurang mampunya mahasiswa mengerjakan soal atau tugas yang sulit, terkadang banyak mahasiswa tidak bisa meyelesaikan masalah tersebut, oleh karena itu berpikir secara kreatif tentunya menjadi modal untuk kehidupan selanjutnya bagaimana memiliki kemampuan untuk menghadapi serta menyelesaikan masalah terutama didalam belajar, secara tidak langsung berbagai pelajaran dan tugas yang diberikan dapat melatih kemampuan untuk berpikir kreatif sekalipun itu sulit dengan berdiskusi bersama teman dan bantuan tutor les juga tentunya sudah membantu meyelesaikan tugas yang sulit. Kemampuan untuk berkembang dalam belajar juga harus dapat dimiliki oleh setiap mahasiswa dalam hal ini adalah mahasiswa membaca banyak buku atau referensi sebagai sumber untuk belajar karena membaca buku dan referensi sebanyakbanyaknya dapat memperluas pengetahuan dan mendatangkan banyak pembelajaran baru yang 
pada kenyataannya pada saat ini mahasiswa masih mengabaikannya. Kemudian berpikir luas dalam belajar yaitu menemukan ide-ide atau informasi yang diperoleh ketika proses pembelajaran berlangsung memiliki cara berpikir kreatif tanpa ide yang dimiliki dan informasi yang didapat mahasiswa tidak akan bisa memperluas cara belajarnya. Mahasiswa harus mampu menilai sendiri hasil belajarnya yaitu harus percaya dan yakin terhadap tugas yang dikerjakan dan hasil yang diperoleh nantinya.

Hasil penelitian ini sejalan dengan penelitian yang dilakukan oleh Ramadhan Wedha Yoga, (2013) yang berjudul "Pengaruh Kreativitas Belajar dan Sikap Kerja Siswa Terhadap Kesiapan Kerja Pada Siswa Kelas XII SMK Negeri 2 Pengasih". Dari penelitian ini disimpulkan bahwa kreativitas belajar berpengaruh terhadap kesiapan kerja pada siswa kelas XII SMK Negeri 2 Pengasih. Hal ini ditunjukkan oleh persamaan garis linear sederhana $Y=49,161+0,295 \mathrm{X} 1$, dengan nilai koefisien korelasi bernilai positif 0,295 , dengan nilai $\mathrm{t}_{\text {hitung }}=5,591>\mathrm{t}_{\text {tabel }}=1.65$ pada taraf signifikansi $5 \%$ dan kontribusi yang diberikan sebesar $12,5 \%$.

\section{Soft Skill terhadap Kesiapan kerja}

Pengaruh soft skill sebesar 0,422 dilihat dari uji analisis regresi linear berganda ini bisa disebabkan karena mahasiswa belum menguasai dirinya sepenuhnya, menajemen waktu mahasiswa yaitu kedisplinan sehari-hari ketika jadwal masuk kuliah terkadang masih ada yang sering terlambat, mahasiswa yang baik adalah mahasiswa yang sudah mempersiapkan waktunya dan membagi waktunya tertutama tanggung jawab kedisplinan yang nantinya yang akan diperoleh ketika memasuki dunia kerja, kejujuran mahasiswa pada saat mengerjakan atau pada saat ujian tidak jujur arti kata berlaku curang atau mencontek, sikap jujur seharusnya sudah ditanamkan oleh setiap mahasiswa dalam dirinya berlaku jujur akan mempengaruhi kehidupannya di lingkungan luar terutama ketika memasuki dunia kerja, mengontrol emosi dan beradaptasi juga perlu dilihat dan harus dikuasai oleh mahasiswa sendiri, dapat berkomunikasi dan bekerja sama dengan orang lain arti kata baik berkomunikasi dengan orang lain yang berguna untuk membangun hubungan baik dengan orang lain. Soft skill menjadi identitas yang melekat pada diri seorang individu terutama pada diri mahasiswa. Pada dasarnya kemampuan Soft skill harus dimiliki oleh setiap lulusan perguruan tinggi yang diperlukan untuk mahasiswa pada saat mencari pekerjaan setelah lulus.

Pengaruh Soft Skill terhadap Kesiapan Kerja sesuai dengan penelitian yang dilakukan oleh Novia (2017) yang berjudul "Pengaruh Soft Skill Terhadap Kesiapan Kerja Menghadapi Masyarakat Ekonomi ASEAN Pada Mahasiswa S1 Fakultas Binis dan Ekonomika Universitas Surabaya”. Dari penelitian ini disimpulkan bahwa soft skill berpengaruh terhadap kesiapan kerja menghadapi masyarakat ekonomi ASEAN pada mahasiwa S1 fakultas bisnis dan ekonomika Universitas Surabaya. Hal ini ditunjukkan oleh persamaan garis linear sederhana $\quad \mathrm{Y}=0,472+0,870 \mathrm{X}$. yang menunjukkan pengaruh positif dan signifikan Soft Skill terhdap Kesiapan Kerja dengan nilai koefisien bernilai positif 0,870 .

\section{Kreativitas Belajar dan Soft Skill terhdap Kesiapan Kerja}

Berdasarkan hasil penelitian pada uji hipotesis secara simultan dengan menggunakan uji $\mathrm{F}$ menunjukkan bahwa terdapat pengaruh yang positif dan signifikan antara Kreativitas Belajar dan Soft Skill terhadap Kesiapan Kerja Mahasiswa program studi Pendidikan Bisnis 2016 Fakultas Ekonomi Univeristas Negeri Medan. Hal ini ditunjukkan dengan diperolehnnya nilai $F_{\text {hitung }}$ sebesar $=20,773$ lebih besar dari $\mathrm{F}_{\text {tabel }}=3,10(20,773>3,10)$ dengan taraf signifikan $=0,000$ lebih kecil dari 0,05 dengan alpha 5\%. Maka dapat disimpulkan ada pengnaruh positif dan signifikan antara Kreativitas Belajar dan Soft Skill Mahasiswa terhadap Kesiapan Kerja Mahasiswa program studi Pendidikan Bisnis 2016 Fakultas Ekonomi Universitas Negeri Medan. Dengan demikian, hipotesis penelitian diterima dan diuji kebenarannya secara statistik.

Sementara berdasarkan hasil analisis regresi diperoleh $\mathrm{R}$ square sebesar 0,309 atau 30,9\% yang berarti Kesiapan Kerja mahasiswa program studi Pendidikan Bisnis 2016 Fakultas Ekonomi Universitas Negeri Medan dipengaruhi oleh Kreativitas Belajar dan Sof Skill mahasiswa sebesar 30,9\%, sedangkan 
sisanya sebesar $69,1 \%$ dipengaruhi oleh faktor lainnya yang tidak disebutkan dalam penelitian ini.

Dari hasil penelitian tersebut, dapat disimpulkan bahwa terdapat pengaruh Kreativitas Belajar dan Soft Skill terhadap Kesiapan Kerja mahasiswa Program Studi Pendidikan Bisnis 2016 Fakultas Ekonomi Universitas Negeri Medan. Artinya, semakin baik Kreativitas Belajar dan Soft Skill mahasiswa maka semakin baik pula Kesiapan Kerja mahasiswa. Hasil ini sekaligus membuktikan bahwa hipotesis dalam penelitian yang menyatakan bahwa ada pengaruh yang signifikan Kreativitas Belajar dan Soft Skill mahasiswa terhadap Kesiapan Kerja mahasiswa program studi Pendidikan Bisnis 2016 Fakultas Ekonomi Universitas Negeri Medan.

\section{KESIMPULAN}

Variabel Kreativitas Belajar (X1) ada pengaruh positif dan signifikan terhadap kesiapan Kerja Mahasiswa program studi Pendidikan Bisnis 2016 Fakultas Ekonomi Universitas Negeri Medan. Variabel Soft Skill (X2) ada pengaruh positif dan signifikan terhadap Kesiapan Kerja mahasiswa program studi Pendidikan Bisnis 2016 Fakultas Ekonomi Universitas Negeri Medan. Hasil dari pengujian secara simultan (Uji F) bahwa Kreativitas Belajar dan Soft Skill mahasiswa memiliki pengaruh yang signifikan terhadap Kesiapan Kerja mahasiswa program studi Pendidikan Bisnis 2016 Fakultas Ekonomi Universitas Negeri Medan

\section{REFERENSI}

Abidin, Riska. 2018. Pengaruh Persepsi Siswa Tentang Kometensi Kejujuran, Penguasaaan Soft Skill, dan Kematangan Karir Terhadap Kesiapan Kerja Siswa Kelas XII Akuntansi SMK Negeri 2 Magelang Tahun 2014/2015. Economic Education Analysis Journal. Vol 4 No 2.

Arikunto, Suharsimi. 2010. Prosedur Penelitian Suatu Pendekatan Praktik. Jakarta: Rineka Cipta.
Badri, Sutrisno. 2012. Metode Statistik Untuk Penelitian Kuantitatif. Yogyakarta: Ombak

Chaplin. 2011. Kamus Lengkap Psikologi (Dictionary Of Psychology) Penerjemah: Dr. Kartini Kartono. Jakarta: Raja Grafindo.

Chietra. 2008. Psikologi Umum http://one.indiskripsi.com/node/6321

Dalyono. 2005. Psikologi Pendidikan. Jakarta: Rineka.

Danim, Sudarwan. 2014. Psikologi Pendidikan. Bandung: Alfabeta.

Datadiwa, Dito. 2015. Analisis Faktor-faktor Yang Mempengaruhi Kesiapan Kerja Siswa SMK Negeri Warureja Tahun 2014. Economic Education Analysis Jounal. Vol 4. No.1

Delita, Fitra, Dkk. 2016. Penigkatan Soft Skill dan Hard Skills mahasiswa melalui Project-Based Learning Pada Mata Kuliah Perencanaan Geografi. Jurnal Geografi. Vol 8. No.2

Elfindri. 2010. Soft Skill Untuk Pendidik. Jakarta. Baduesse Media.

Kardimin, Ahkmad. 2004. Strategi Melamar Kerja dan Bimbingan Karir. Yogyakarta: Pustaka Pelajar.

Lubis, Desi Wulandari. 2015. Pengaruh Pengalaman Kerja Industri dan Motivasi Memasuki Dunia Kerja Terhadap Kesiapan Kerja Siswa SMK Swasta Satrya Budi Karang Rejo Simalungun T.P 2014/2015. Skripsi Fe Unimed.

Lucas, Novia, Dkk. 2017. Pengaruh Soft Skill Terhadap Kesiapan Kerja Menghadapi Masyarakat Ekonomi ASEAN Pada Mahasiswa S1 Fakultas Bisnis dan Ekonomika Univeristas Surabaya. Jurnal Ilmiah Mahasiswa Universitas Negeri Surabaya. Vol. 6 No 2.

Marwanti dan Yuriani. 2006. Studi Tentang Kesiaan Kerja Mahasiswa Pendidikan Tata Boga Jurusan Pendidikan Kesejahteraan Keluarga 
Fakultas Teknik Universitas Negeri Yogyakarta. Laporan Penelitian. Fakultas Teknik - UNY

Mudlofir, Ali. 2012. Pendidik Profesinal. Jakarta. PT Raja Grafindo Persada.

Munandar, Utami. 2009. Pengembangkan Kreativitas Anak Berbakat. Jakarta : Rineka Cipta.

Noordiansyah, Muchammad. 2014. Kontribusi Dalam Praktik Pemesinan dan Motivasi Kerja Siswa Terhadap Kesiapan Kerja. E-Jurnal Pendidikan Teknik Mesin. Volume 2, Nomor 2.

Purwandri. 2007. Model Pembelajaran Berbasis Soft Skill Utuk Mengembangkan Kecakapan Sosial Anak Tuna Laras di Sekolah Luar Biasa. Laporan Penelitian. Yogyakarta: Fakultas Ilmu Keolahragaan.

Rozaini, Noni. 2018. Pengaruh Hasil Belajar Komunikasi Bisnis dan Kematangan Vokasional Terhadap Kesiapan Kerja. Jurnal Niagawan. Vol 7 No 1.

Sailah, Illa. 2008. Pengembangan Soft Skill di Perguruan Tinggi. Bogor. Tim KBK dan Soft Skill Ditjen Pendidikan Tinggi.

Santi. 2010. Pengaruh Kreativitas Belajar dan Motivasi Berprestasi Terhadap Hasil Belajar Mata Diklat Kewirausahaan Siswa Kelas XI SMK Negeri 1 Tebing Tinggi T.A 2010/2011.

Sianipar, Irma Yanti. 2017. Pengaruh Motivasi Berprestasi dan Perhatian Orang Tua Terhadap Kesiapan Kerja Mahasiswa Pendidikan Tata Niaga Stambuk 2013 Universitas Negeri medan dalam mennghadapi MEA. Skripsi FE Unimed.

Simamora, Laris. 2019. Pengaruh Soft Skill, Indeks Prestasi belajar, dan Praktik Pengalaman Lapangan (PPL) Terhadap Kesiapan Menjadi Guru Pada Mahasiswa UNIMED Prodi
Pendidikan Ekonomi Angkatan 2015. Skripsi FE UNIMED.

Sunardi. 2013. Pengukuran Kreativitas. Diambil dari http://www.file.upi.edu, Pada Tangggal 20 oktober 2019.

Surya, Mohamad. 2004. Psikologi Pembelajaran dan Pengajaran. Bandung: Bani Quraysi.

Wagiran. 2013. Model Penguatan Soft Skills Dalam Mewujudkan Calon Guru Kejuruan Profesional Berkarakter. Jurnal Kependidikan. Yogyakarta: LPPM UNY.

Wedha, Ramadhan. 2013. Pengaruh Kreativitas Belajar dan Sikap Kerja Siswa Kelas XII SMK Negeri 2 Pengasih. Skripsi FT UNY.

Widharso, Wahyu. 2009. Evaluasi Soft Skill Dalam Konteks Pembelajaran. Diakses 20 oktober 2019. https://widhiarso.staff.ugm.ac.id/files Imakalah_soft_skills.pdf

Yulianto, Amzar. 2015. Pengaruh Keaktifan Sisa Berorganisasi Terhadap Peningkatan Soft Skill dan Presta bsi Belajar Siswa Kelas XI Kompetensi Keahlian Tekik Pemesinan SMK Muhammadiyah Prambanan Tahun jaran 2014/2015 . Skripsi FT UNY

Zamtinah, Imam Mustholiq \& Sukir. 2004. Pengaruh Informasi Dunia Kerja dan Pengalaman Praktik Industri Terhadap Kesiapan Kerja Mahasiswa Tekni Elektro FT UNY. Laporan Penelitian. Fakultas Tekni UNY.

Zuliawati, Nurul. 2016. Pengaruh Kreativitas dan Motivas Kerja Terhadap Produktivitas Guru Pendidikan Agama Islam Sekolah Dasar Sekecamatan Baturetno kabupaten Wonogiri. Jurnal Pendidikan. Volume1. No 1. 